\title{
Sedef Hastalığında kullanılan Aloe vera, Smilax excelsa ve Juniperus oxycedrus Bitkilerinin Yaprak Anatomik Özellikleri
}

Mine Koçyiğit ve Kübra Tümer

öz

Sedef hastalığı-psöriazis (psoriazis), keskin sınırlı, eritemli plak veya papüller üzerinde yerleşmiş parlak, sedefi-beyaz pullarla karakterize, kronik seyirli, bulaşıcı olmayan inflamatuvar bir hastalıktır. Pulların renginden dolayı halk arasında 'Sedef Hastalığı' olarak bilinmektedir. Bu çalışmada Türkiyede halk arasında sedef hastalığında kullanılan bitkilerden üçünün (Juniperus oxycedrus L. (Cupressaceae), Aloe vera (L.) Burm.f. (Xanthorrhoeaceae) ve Smilax excelsa L. (Smilacaceae) yaprak anatomileri incelenmiştir. Sedef hastalığında Juniperus oxycedrus'un dallarından elde edilen Ardıç katranı denilen yağlı madde, Aloe vera bitkisinin yaprağının merkezinde parankima içinde depolanan jeli, Smilax excelsa bitkisinin ise kökleri kullanılmaktadır. Bu üç bitkiye ait yaprak enine kesitleri ve yüzeysel kesitlerinin fotoğrafları sunulmuştur. Stoma indeksleri ilk kez bu çalışmada hesaplanmıştır.

Anahtar Kelimeler: Sedef Hastalığı, Juniperus, Aloe, Smilax, yaprak anatomisi, Türkiye
Mine Koçyiğit ve Kübra Tümer

Istanbul University, Faculty of Pharmacy, Department of Pharmaceutical Botany, 34116 Beyazit, Istanbul, Turkey

Sorumlu Yazar:

Mine Koçyiğit

e-posta: minekocyigit@hotmail.com/mkocyigit@istanbul.edu.tr

Submitted / Gönderilme: 03.04.2017

Revised / Düzeltme: 07.04.2017

\section{GIIRIş}

Sedef hastalığı-psöriazis (psoriasis), keskin sınırlı, eritemli plak veya papüller üzerinde yerleşmiş parlak, sedefibeyaz pullarla karakterize, kronik seyirli, bulaşıcı olmayan inflamatuvar bir hastalıktır (1). Pulların renginden dolayı halk arasında 'Sedef Hastalığı' olarak bilinmektedir. Hastalık sıklıkla saçlı deri, diz, dirsek ve eklemlere yerleşen lezyonlarla seyretmektedir (2).

Psoriasis hakkında ilk bilgiler Celsus'a (M.Ö.25-M.S.-45) aittir. Daha sonra Hipokrat (M.Ö.460-375) pullu döküntüler olarak sinıflandırdığı psoriasise benzer lezyonları tanımlamıştır ve bunları lopoi (lepo, deskuamasyon) olarak adlandırmıştır. Galen (M.S.133-200) hastalığı daha detaylı olarak tanımlamıştır. Hastalığın tipik özelliklerini tanımlayan Robert Willian (1798) ise hastalığın lepradan farklı ve özel bir hastalık olduğunu belirtmiştir. Psoriazisi günümüzde tanımlandığ 1 şekliyle ilk kez Ferdinand Hebra (1841) olmuştur (3). Dünyanın hemen her yerinde görülen hastalığın sıklığı etnik, coğrafik ve çevresel faktörlere bağlı olarak değişiklik göstermektedir (4). Epidemiyolojik çalışmalarda psoriazis sıklı̆̆ $\% 0.2$ ile \%4.8 arasındadır. En yüksek prevelans Norveç’tedir. Ülkemizde prevelansı 
\%1.3’tür (5). Çocuklarda rastlanma sıklığı \%1.1 olarak bulunmuştur. Hastaların neredeyse 2/3'ünde hastalık hafif seyreder ve cilt yüzeyinin \%3'ünden daha azı etkilenir, geriye kalanlarda ise derinin daha geniş yüzeylerine yayılmaktadır. Erken yaşta başlayan ve aile öyküsü bulunanlarda hastalığın prognozu daha kötü olmaktadır (6). Hastalık hem çocuklarda hem erişkinlerde olmak üzere beyaz ırkta en fazla görülür (7). Erkek ve kadınlarda eşit sıklıktadır ancak kadınlarda genellikle daha erken yaşta başlar (8). Hastalığın genetik geçişli olduğunu gösteren pek çok çalışma olmasına rağmen bu geçişin nasıl olduğu kesin olarak bilinmemektedir (9).

Türkiye'de halk arasında sedef hastalığında kullanılan bitkilerden üçü Juniperus oxycedrus, (Cupressaceae), Aloe vera, (Xanthorrhoeaceae), ve Smilax excelsa (Smilacaceae)'dır $(10,11,12)$. Juniperus cinsine ait 8 tür ülkemizde doğal olarak yetişmektedir (10). Juniperus oxycedrus yaprak ve kozalakları farklı hastalıklarda kullanılmaktadır $(13,14)$. Sedef hastalığında ise bu bitkinin dallarından elde edilen Ardıç katranı (Juniperi pix, Oleum Cadinum-Cade oil) denilen yağlı madde kullanılmaktadır $(15,16)$. Ardıç katranı geniş ölçüde dermatolojide insan ve hayvanlardaki egzama ve diğer cilt problemlerinin tedavisinde de kullanılmaktadır (17).

Aloe vera bitkisi, bazen 'mucizevi bitki' olarak tanımlanmakta ve yüzyıllardır insanlık tarafından özellikle cilt hastalıklarının tedavisinde, mide rahatsızlıkları, saç dökülmesi, böbrek rahatsızlıkları gibi daha birçok hastalığın tedavisinde kullanılmaktadır (18). Aloe cinsi Afrika kökenli olup ülkemizde kültürü yapılmaktadır (19) ve tedavide kullanımı neredeyse 6000 yll öncesine dayanmaktadır (20). Bu cins dal uçlarında sulu, yeşil ve kenarları dikenli rozet yapraklar taşıyan, çok yıllık etli bitkilerdir. Yaprakları etli, sert, benekli, mızrak şeklinde tüysüz, tepeleri keskin ve kenarları dikenlidir. Yaprakların yaralanması veya parçalanması durumunda yapışkan jelimsi bir sıvı yayılır. Cilt hastalıklarında özellikle bu sıvı etkili olarak kullanılmaktadır (21).

Smilax (saparna) cinsi tırmanıcı, dikenli gövdeli çok yıllık bitkilerdir. Ülkemizde doğal olarak 2 tür yetişmektedir (22). Yaprakları alternan dizilişli lamina ovat kordat veya sagittat ve saplı olup stipulları metamorfoze olarak sülük şeklini almıştır. Çiçekler yaprakların koltuğunda, salkım veya basit şemsiye durumundadır. Meyva kırmızı veya kahverengidir. Bu cinsin Orta Amerika' da yetişen Smilax ornata, S.medica, S.officinalis ve S.utilis türlerinin kökleri Sarsaparillae radix (Saparna kökü) adı verilen ve bir çok kodeks ve farmakopede kayıtlı olan bir drogdur. Bileşiminde saponozit yapısında bileşikler bulunur. Deri hastalıklarında kullanılır. Sarsaparilla kökleri yüzyıllarca Orta ve Güney Amerika yerli halkı tarafından cinsel iktidarsızlık, romatizma, cilt hastalıkları ve fiziksel zayıflık için kullanılmıştır. Amazon'da birçok şaman ve tıp adamı lepra ve cilt hastalıklarının (psoriasis ve dermatit) tedavisinde kullanmıştır (23). Klinik araştırmalar sedef hastalığı, egzama, akne ve cüzzam gibi cilt hastalıkları için geleneksel sarsaparilla kullanımını doğrulamıştır (24).

\section{GEREÇ VE YÖNTEM}

Juniperus oxycedrus (ISTE 74991) ve Smilax excelsa (ISTE 84186) bitkilerine ait yapraklar, İstanbul Üniversitesi Eczacillk Fakültesi Herbaryumundan (ISTE), Aloe vera bitkisine ait yapraklar ise İstanbul Üniversitesi Botanik Bahçesinden temin edilmiştir. Taze örnekler \%70'lik alkol içerisinde bekletilmiştir, herbaryum örnekleri ise \% $\% 5^{\prime}$ lik $\mathrm{KOH}$ çözeltisinde bekletildikten sonra kesitler alınmıştır. Alınan kesitler Sartur reaktifi ile boyandıktan sonra incelenmiştir. Anatomik yapılar Olympus marka ışık mikroskobunda görüntülenmiştir ve mikrofotoğraflar çekilmiş ve ölçümler KAMERAM@ programılla yapılmıştır. Stoma indeksi aşağıdaki formülle hesaplanmıştır:

SI= Stoma sayıs $\times 100 /$ Stoma sayıs 1 Epiderma Hücresi Sayıs1

\section{SONUÇ VE TARTIŞMA}

\section{Aloe vera Bitkisinin Yaprak Anatomisi}

Aloe vera'nın yaprağı dış yeşil kabuk ve renksiz iç bölüm olmak üzere iki bölümden oluşmaktadır. İç tabaka jel, müsilaj tabakası veya mezofil olarak tanımlanır. Tibbi etkiye sahip olan bu tabaka berrak, saydam ve renksiz bir kütle halindedir. Aloe vera yaprağı aşağıdaki dokulardan oluşur: Epiderma, klorenkima (Şekil 1), vasküler demetler ve renksiz iç parankima dokusu (Şekil 2).

\section{Epiderma}

Enine kesitte yaprak epiderması hem adaxial (ventral) ve abaxial (dorsal) yüzeylerde üniform bir tabaka oluşturur. Epiderma yaklaşık 25-40 $\mu \mathrm{m}$ kalınlığında, kalın bir kutikula tabakasıyla örtülü hücrelerden meydana gelir. Kalın ve papillalı kutikula tabakası yaklaşık 6-8 $\mu \mathrm{m}$ dir, 20 lamelden oluşmuştur. En dış lamelinde kütin ve mum, iç lamellerde ise önce selüloz, sonraki tabakalarda da pektin maddesi çoktur. Epidermal hücreler yaprakların uzun ekseni ile paralel düzenlenir ve az sayıda kloroplast içermektedir (Şekil 1). 

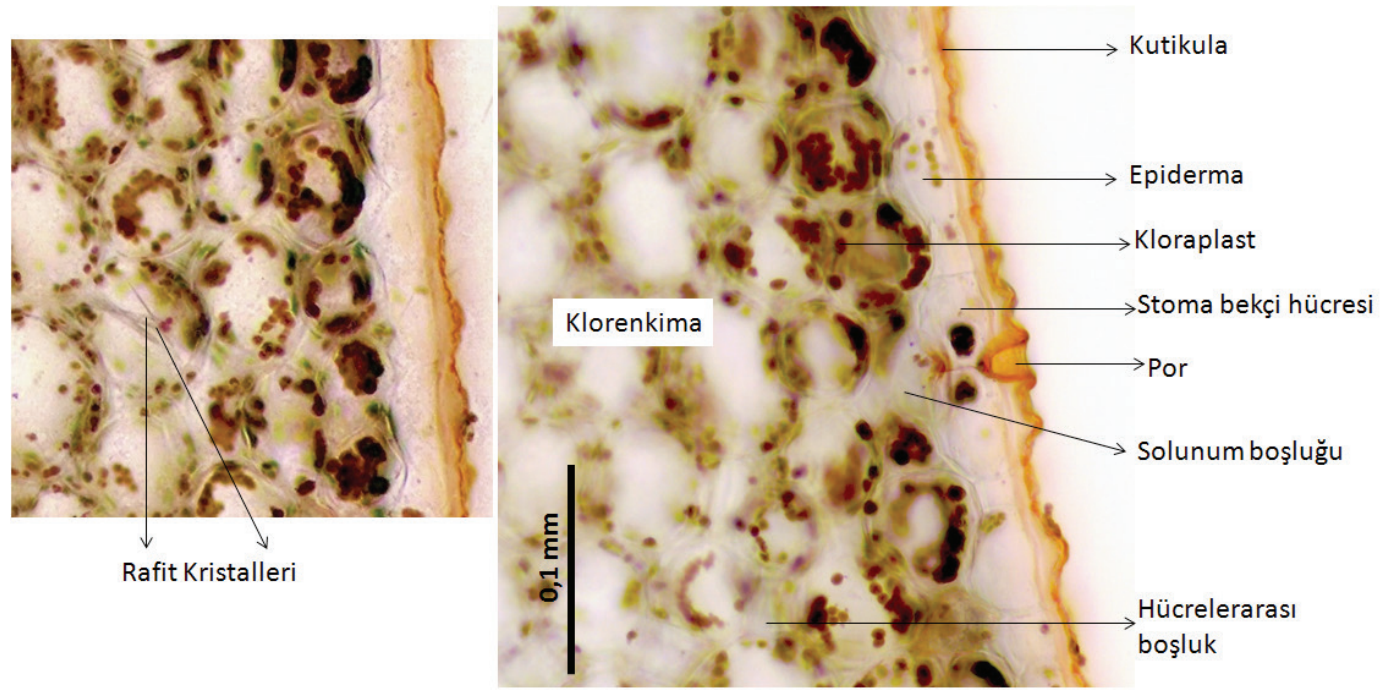

Şekil 1: Aloe vera'nın yaprak enine kesiti ve stoma

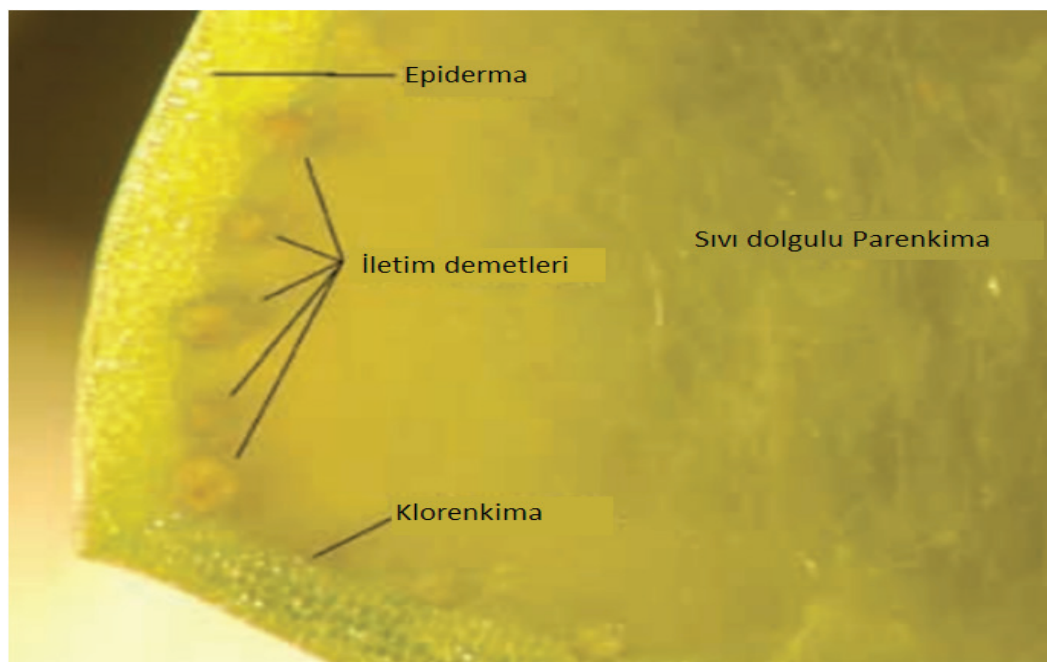

Şekil 2: Aloe vera'nın yaprak enine kesiti

\section{Klorenkima}

Epidermanın hemen altında genellikle 8-10 katman halindedir. (Katman sayısı değişebilir) altıgen veya yuvarlak şekilli, kloroplast içeren klorenkima hücreleri, yaklaşık olarak 50-60 $\mu \mathrm{m}$ genişliğindedir. Bazı hücreler, iğne şeklinde oksalat kristalleri içerebilir. Bu tabaka sünger ve palizat parenkiması tabakalarına ayrılmamıştır. İletim demetleri klorenkimanın hemen altında tek sıra halinde dizilmiştir. (Şekil 2)

\section{Stoma}

Epidermanın her iki yüzeyinde 4-5 komşu hücreye sahip stomalar bulunur. Stomalar epidermayla aynı düzlemde konumlanmıştır. Stoma bekçi hücreleri herhangi bir yardımcı hücreyle çevrili değildir, direkt olarak epiderma hücreleriyle bağlantılıdır. Dorsal yüzeyde stoma indeksi (SI) \%7,84 (Şekil 3), ventral yüzeyde ise \%7,69 (Şekil 4)'dur.

\section{İletim Demeti}

İyi gelişmiş parenkimal hücrelerle çevrilmiştir. Kalburlu borular ve arkadaş hücreleri dardır. Floem çok belirgin değildir ve ksilem dar trakeitlerden oluşur. 


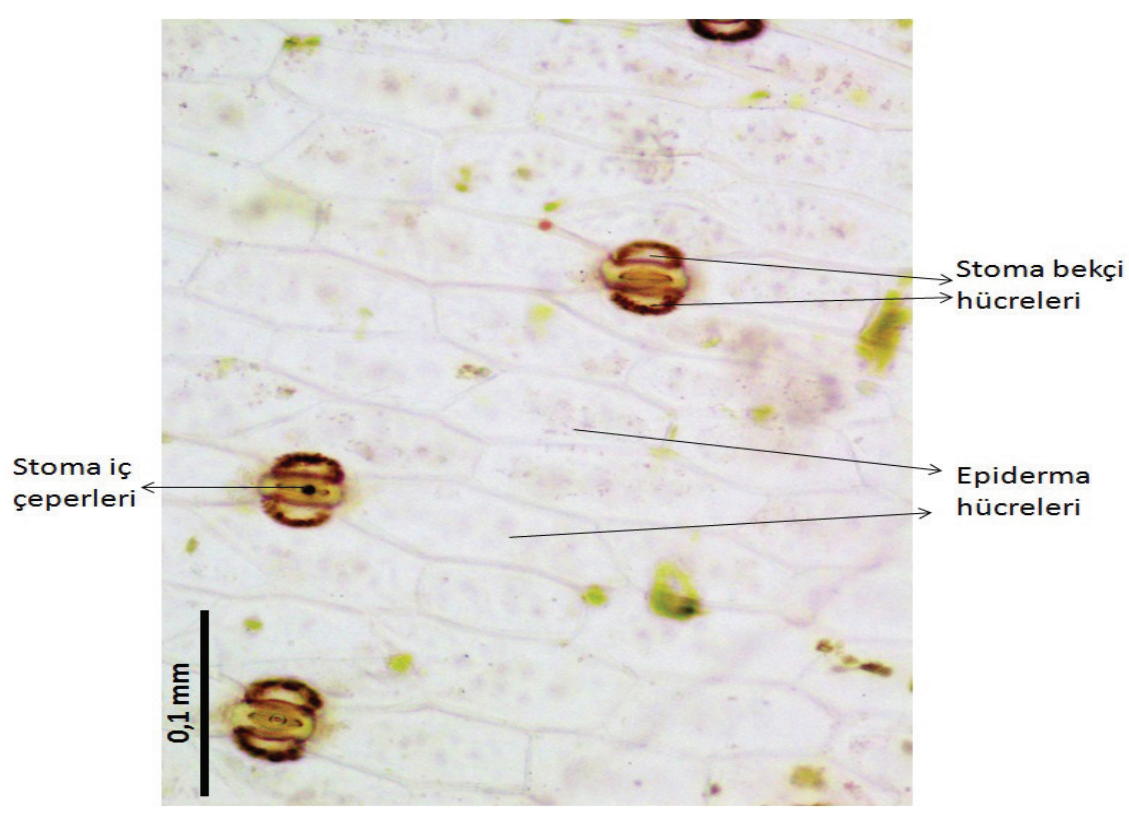

Şekil 3: Aloe vera yaprağının dorsal yüzeyindeki stomaların görünümü

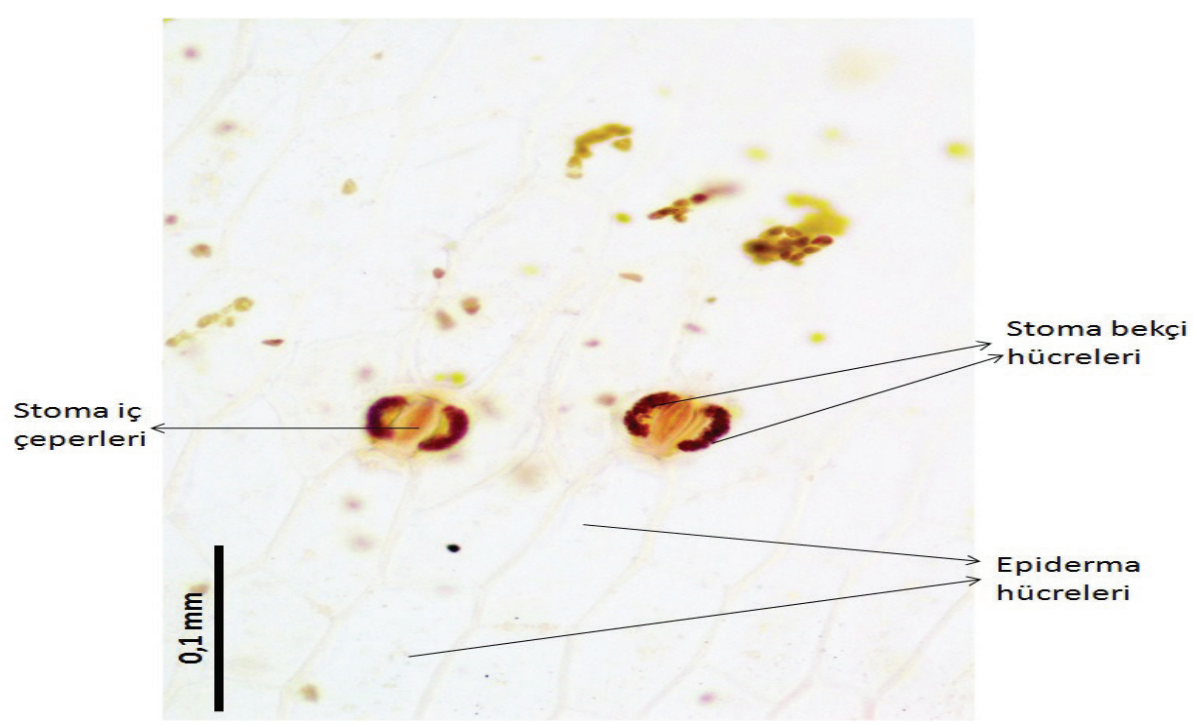

Şekil 4: Aloe vera yaprağının ventral yüzeyindeki stomaların görünümü

\section{Parenkima}

Yaprağın merkezinde bulunan parenkima dokusu büyük parenkima hücrelerinden oluşur. Bu hücreler yaklaşık olarak 400-500 $\mu \mathrm{m}$ çapında, kloroplast içermeyen ve polisakkarit açısından zengin sıvı ile doludur (Şekil 2).

Parenkima dokusunun çevresindeki iletim demetleri ve merkezi parenkima dokusu yaprak çapının büyük bölümünü işgal etmektedir (25-26). Bu açıdan elde edilen sonuçlar daha önceki çalışmalarla uyumludur. Kutikula, epiderma ve klorenkima kabuğu oluşturur.

\section{Juniperus oxycedrus Bitkisinin Yaprak Anatomisi}

Bitkinin bütün yaprakları linear-lanseolattır. Bununla birlikte, enine kesitte bu yapraklar yarı dairesel veya üçgen olarak görülmektedir. Transfüsyon dokusu vaskular demetin 
iki tarafında yer alır (Şekil 5). Juniperus türlerinde heterofili görülür, genç yapraklar iğne şeklinde, olgun yapraklar pulsudur. $\mathrm{Bu}$ çalışmada olgun yapraklar incelenmiştir. Juniperus oxycedrus yapraklarının enine kesitinde ve yüzeysel kesitlerde aşağıdaki anatomik yapılar gözlenmiştir.

\section{Epiderma}

Epiderma hücreleri kalın bir kutikula tabakasıyla kaplıdır. Epiderma hücrelerinin çeperlerinde lignin birikimi gözlenmiştir, bu nedenle sarturla incelenen kesitlerde epiderma çeperi sarı renklidir. Üst epidermal hücreler genellikle kare şeklindedir ve tek katmanlı, kalın çeperli ve genellikle küçük lümenlidir. Üst epidermada bol miktarda stoma vardır (Şekil 6). Alt yüzeyde stoma yoktur. Bu özelliği nedeniyle yaprak epistomatik olarak tanımlanır. Stomalar hegzasitik tiptedir, yani stoma bekçi hücreleri etrafında 6 komşu hücre bulunur. Stom indeksi \% 14, 85 'tir.

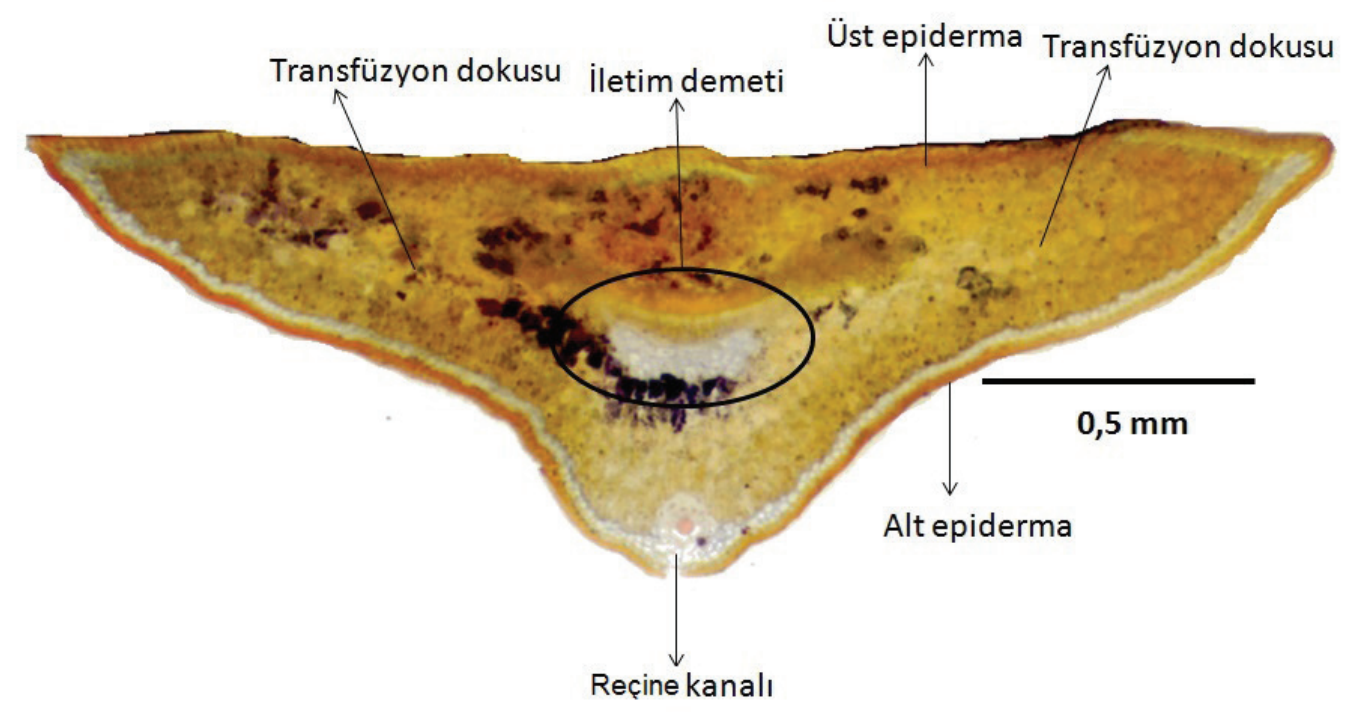

Şekil 5: Juniperus oxycedrus'un yaprak enine kesiti

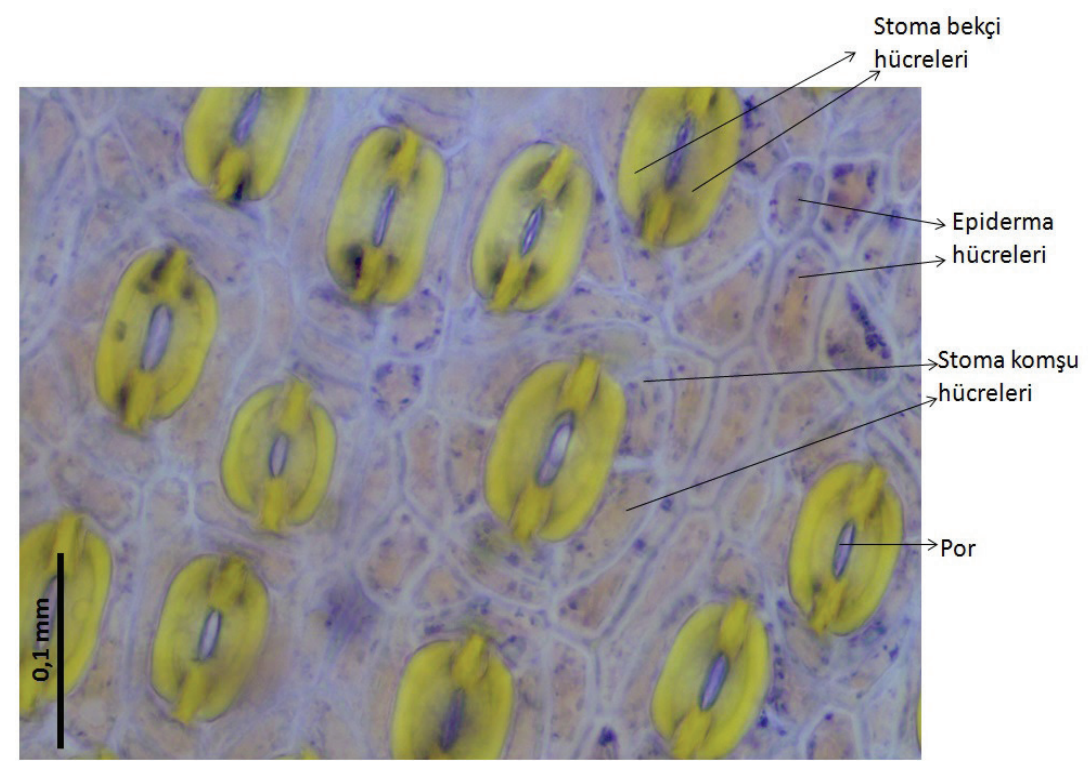

Şekil 6: Juniperus oxycedrus'un yaprak üst yüzeyi 


\section{Hipoderma}

Hipoderma, epiderma tabakasının altındadır. Genellikle tek katmanlıdır, çok küçük lümenli (epidermal lümenden daha küçük)dir. Hipoderma hücreleri, bazen palisat hücreleri arasına kadar girebilir, bu bölgelerde çok tabakalı olarak görülür. Hipoderma tüm alt epidermanın altında ve yaprağın köşelerinde görülür (Şekil 7).

\section{Transfüzyon Dokusu}

Palisat ve sünger parenkiması olarak gözlenir. Palisat parenkiması, ince duvarlı ve kompakt biçimde düzenlenmiş silindirik hücrelerden oluşur. 1-2 tabakalıdır. Sünger parenkiması hücreleri yoğun nişasta granülleri içerir. Genellikle hücreler arası boşlukları bulunur ve oval hücrelerden oluşur. Vasküler demet yaprak merkezinde bulunur ve genellikle yarı daireseldir. Vasküler demette ksilem üst tarafta, floem alt taraftadır. İletim demeti ile hipoderma arasında bir tane büyük reçine kanalı bulunur. Reçine kanalı ince çeperli ve tek sıralı hücrelerden oluşmuştur (Şekil 7).

Juniperus türlerine ait yaprak anatomisi çalışmaları yapılmıştır. Alt türler arasında yaprak anatomisi açısından belirgin farklar olmasa da türler arasında yaprak anatomisinde hipoderma kalınlığı ve salgı kanalının çapı ayırt edici karakterlerdir $(27 ; 28)$. Bu çalışmada sunulan J. oxycedrus bitkisine ait anatomik sonuçlar daha önceki sonuçlarla uyum göstermektedir (29-32). J. oxycedrus'un stoma indeksi ilk kez bu çalışmada belirlenmiştir.

\section{Smilax excelsa Bitkisinin Yaprak Anatomisi}

Smilax excelsa'da yapraklar alternan dizilişli, lamina ovat kordat veya sagittat ve saplı olup stipulları metamorfoze olarak sülük şeklini almıştır. Yaparak enine kesitinde epiderma, mezofil ve orta damarın anatomik özellikleri incelenmiştir (Şekil 8).

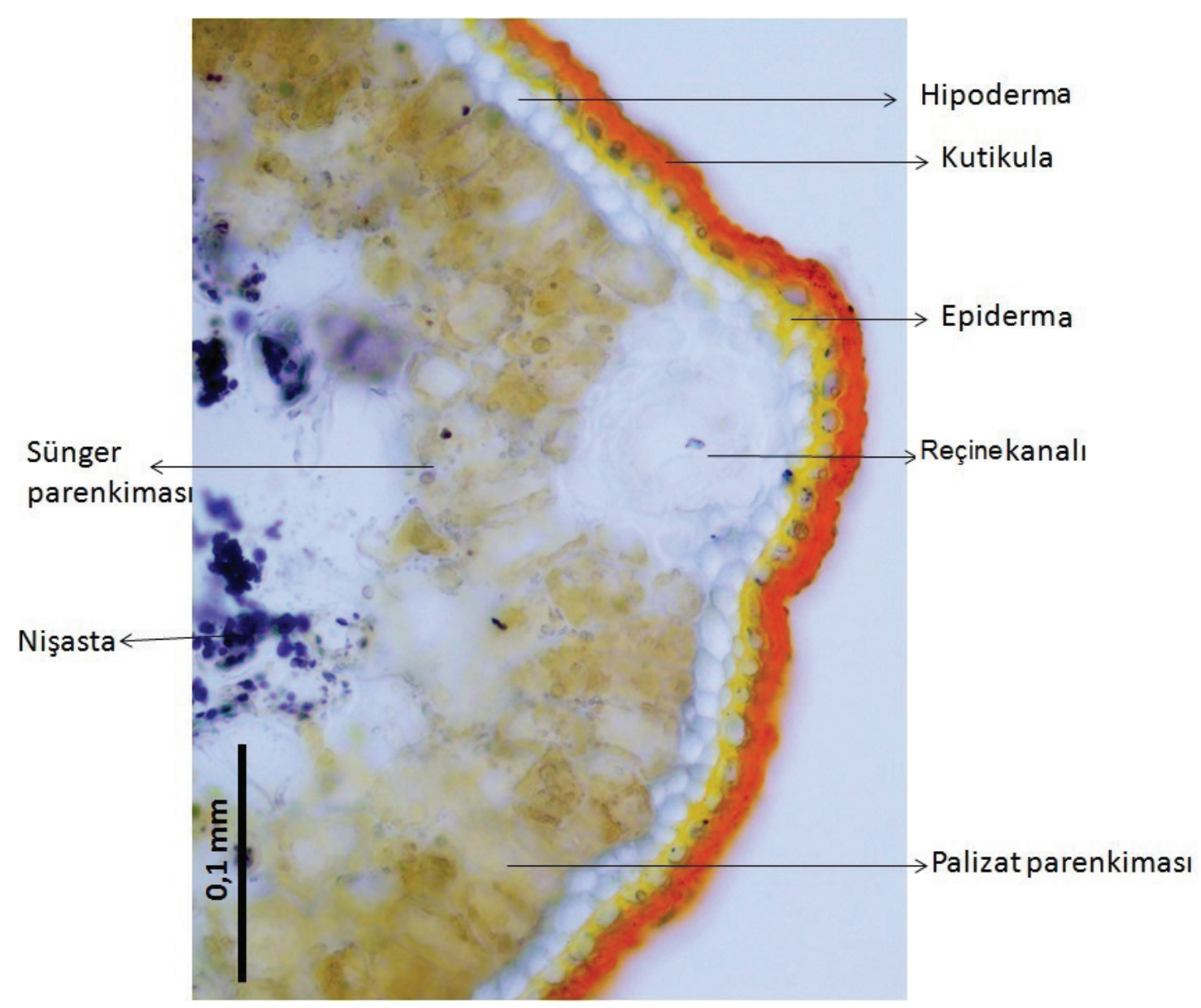

Şekil 7: Juniperus oxycedrus'un yaprak enine kesitinde reçine kanall, hipoderma ve epiderma 


\section{Epiderma}

Stoma bekçi hücreleri epidermal hücrelerle hemen hemen aynı seviyede veya hafifçe üst seviyededir (Şekil 9). Yaprak hipostomatik tiptedir, yani sadece alt yüzeyde stoma bulunur (Şekil 10). Bunun haricinde epidermanın alt ve üst yüzleri arasında belirgin anatomik farklılıklar yoktur (Şekil 11). Stomalar çoğunlukla parasitik özellik göterir, yani birbirine parale konumlanmış iki komşu hücreyle sınırlanmıştır. Stoma indeksi \%18,52'dir. Tek sıralı hücrelerden oluşan epiderma papillalı bir kutikula tabakasıyla kaplıdır.

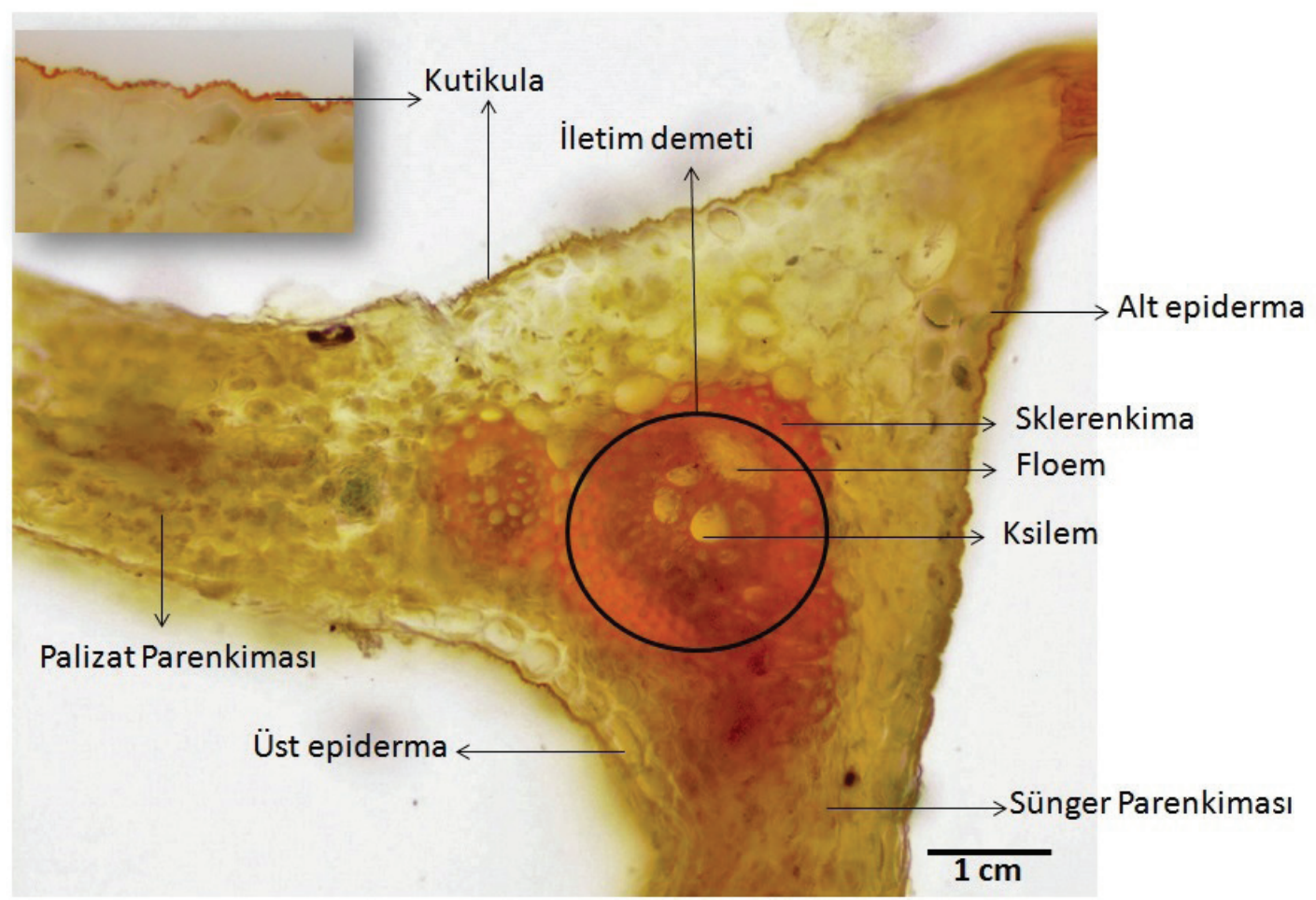

Şekil 8: Smilax excelsa'nın yaprak orta damarının enine kesiti
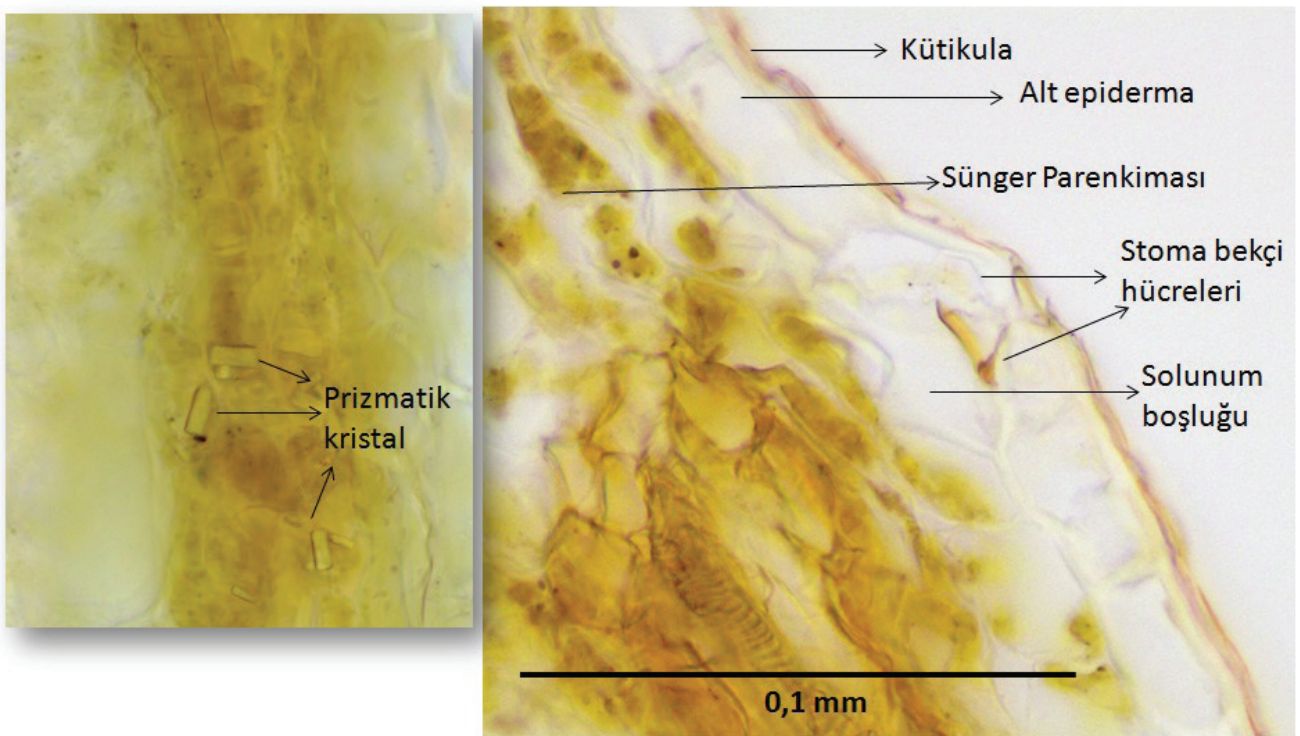

Şekil 9: Smilax excelsa'nın yaprak enine kesitinde stomanın yandan görünümü 


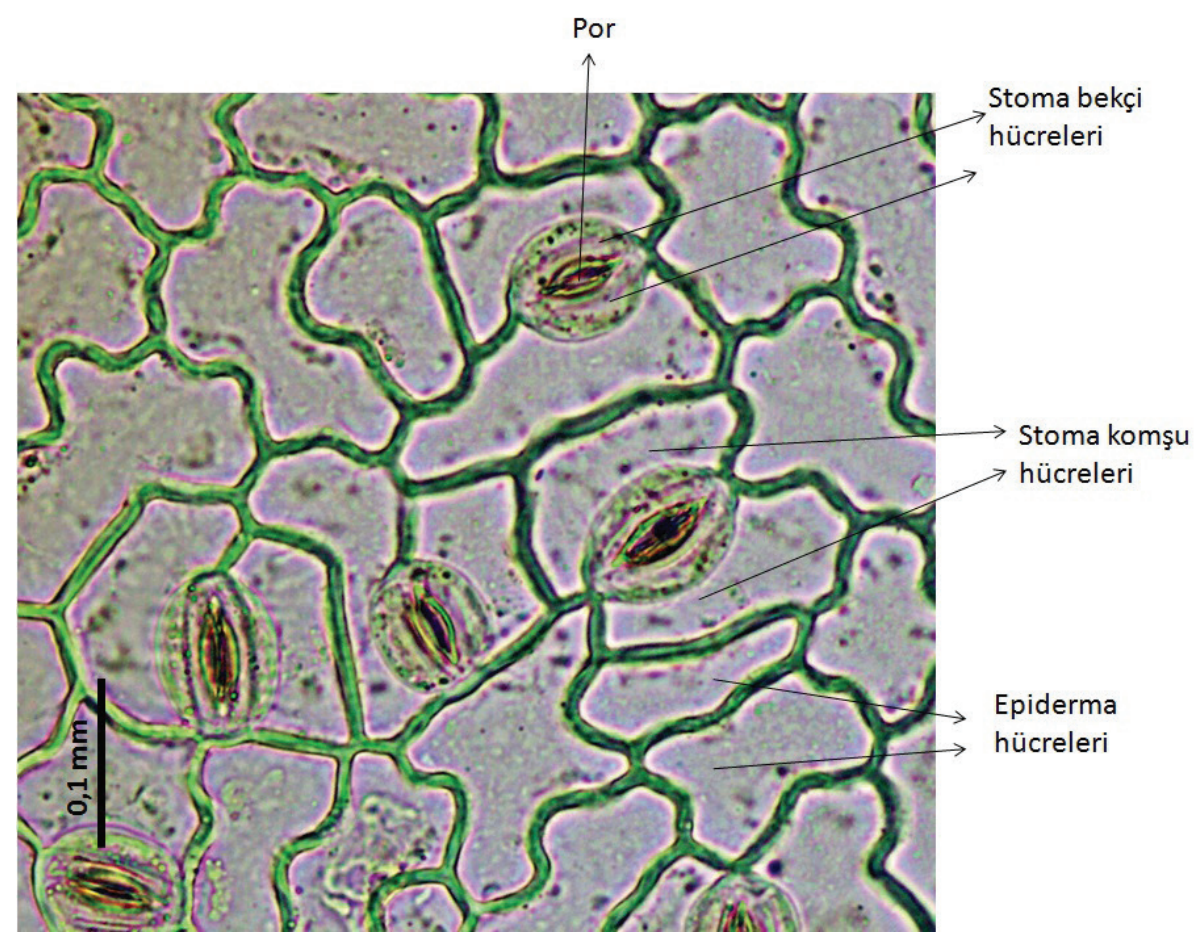

Şekil 10: Smilax excelsa'nın yaprak alt yüzeyi

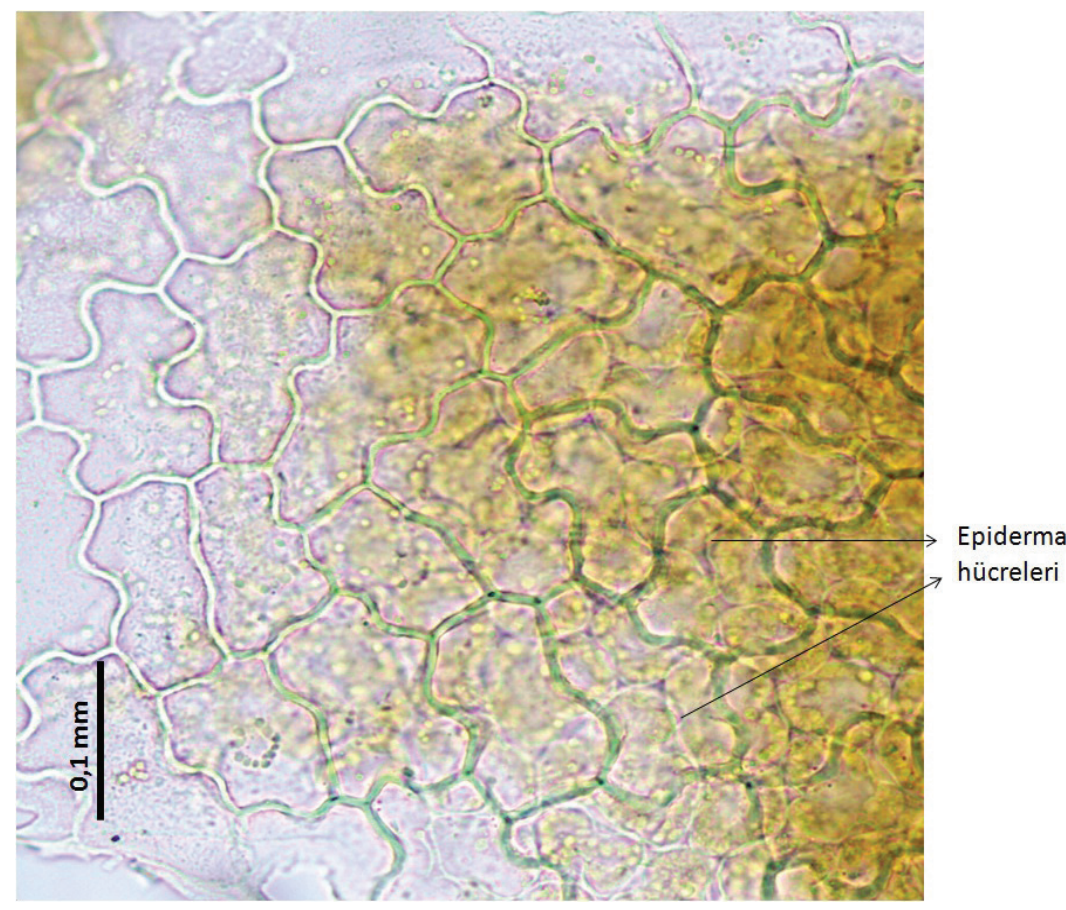

Şekil 11: Smilax excelsa'nın yaprak üst yüzeyi

\section{Mezofil Dokusu}

Yaprak bifasyal tiptedir, alt epidermanın altında sünger parenkiması, üst epidermanın altında ise palizat parenkiması yer alır. Ayrica bol miktarda prizmatik kristal ve rafit demetleri gözlenmiştir (Şekil 12). 


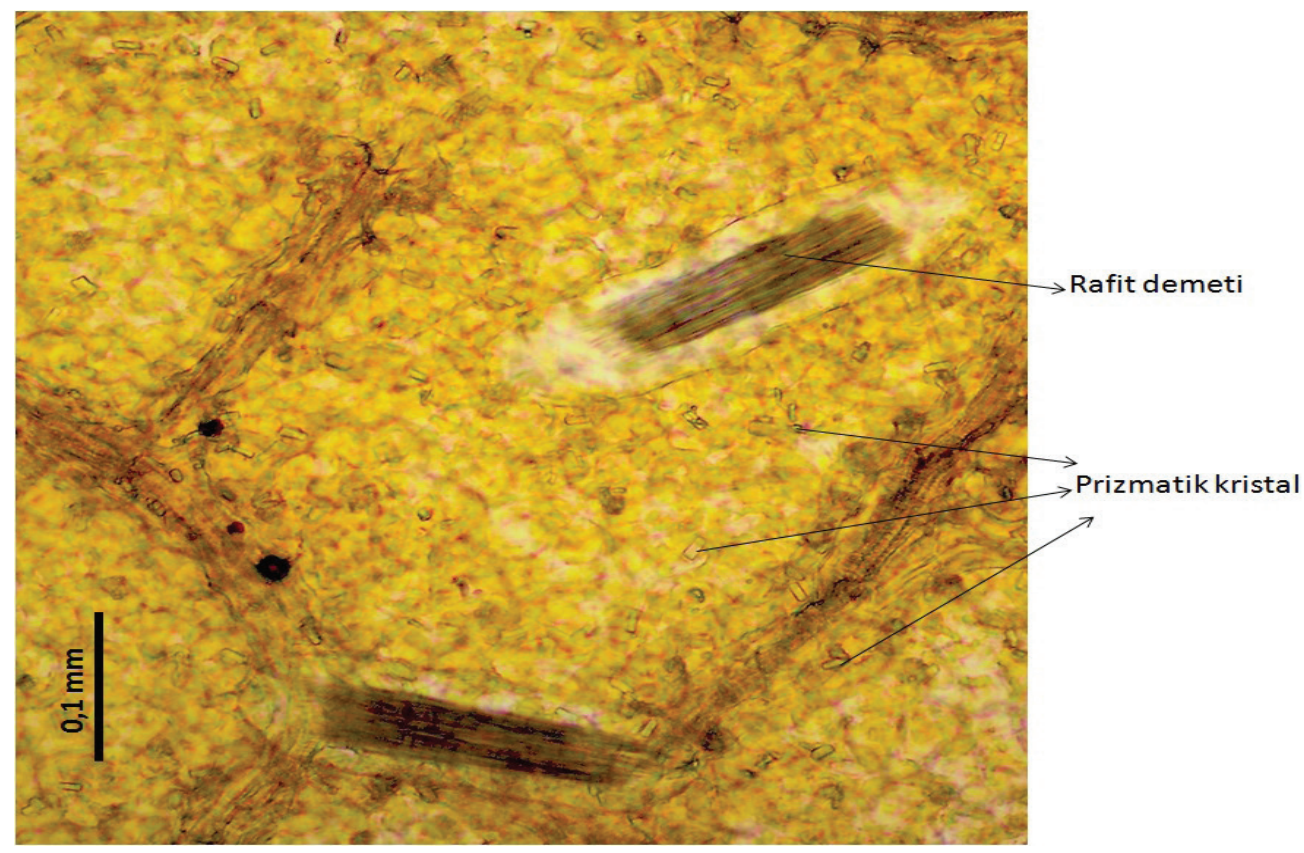

Şekil 12: Smilax excelsa'nın yaprak yüzeysel kesitinde kalsiyum okzalat kristalleri

Smilax cinsine ait bazı türler üzerinde anatomik çalışmalar yapılmıştır (33-36), cinsin yaprakları genellikle çok serttir, bu nedenle, bu türler için anatomik yöntemlerin her bitki için test edilmesi ve uyarlanması gerekir (37-38), ancak Smilax excelsa'nın yaprak anatomisi ilk kez bu çalışmada sunulmaktadır.
Leaf Anatomical Features of Juniperus oxycedrus, Aloe vera and Smilax excelsa used in psoriasis

\section{ABSTRACT}

Psoriasis is a chronic, noncommunicable inflammatory disease characterized by shiny, pearlescent-white scales embedded on papules and erythematous plaques. Because of the color of the squamouses, it is popularly known as 'Psoriasis'. In this study leaf anatomies of three plants (Juniperus oxycedrus L. (Cupressaceae), Aloe vera (L.) Burm.f. (Xanthorrhoeaceae), and Smilax excelsa L. (Smilacaceae) were investigated among the plants used in psoriasis in Turkey. In psoriasis, a fatty substance called juniper tar obtained from the branches of Juniperus oxycedrus, a gel stored in the parenchyma at the center of the leaf of the Aloe vera, and roots of the Smilax excelsa are used. Photographs of leaf cross-sections and superficial cross-sections of the three plants are presented. Stomatal index were calculated for the first time in this study.

Keywords: Psoriasis, Juniperus, Aloe, Smilax, leaf anatomy, Turkey

\section{REFERENCES}

1. Gudjonsson JE, Elder JT. Psoriasis, Fitzpatrick's Dermatology in Medicine Volume 1. Mc Graw-Hill, New York. 2008, pp. 169-193.

2. Tüzün B, Tüzün Y. Psoriasis dipnotları. Nobel Tip Kitabevi, İstanbul. 1998.

3. Romiti R, Maragno L, Arnone M, Takahashi M. Psoriasis in childhood and adolescence. An Bras Dermatol 2009; 9-20.

4. Gudjonsson JE, Elder JT. Psoriasis: Epidemiology. Clin Dermatol 2007; 25: 46-535.
5. Kundakcı N, Türsen U, Babiker MO, Gürgey E. The evaluation of the sociodemographic and clinical features of Turkish psoriasis patients. Int J Dermatol 2002; 41: 4-220.

6. Barker JNWN. Genetic aspects of psoriasis. Clin Exp Dermatol 2001; 26: 5-321.

7. Howard R, Tsuchiya A. Adult skin disease in the pediatric patient. Dermatol Clin 1998; 16: 593-608.

8. Elder JT, Nair RP, Guo SW, Henseler T, Christophers E, Voorhees JJ. The genetics of Psoriasis. Arch Dermatol 1994; 130: 24-216. 
9. Christophers E. Psoriasis-epidemiology and clinical spectrum. Clin Exp Dermatol 2001; 26: 20-314.

10. Polat R, Sat1l F. An ethnobotanical survey of medicinal plants in Edremit Gulf (Balıkesir - Turkey). J Ethnopharmacol 2012; 139: 626-41.

11. Güzel Y, Güzelşemme M, Miski M. Ethnobotany of medicinal plants used in Antakya: A multicultural district in Hatay Province of Turkey. J Ethnopharmacol 2015; 174: 118-52.

12. Saltan FZ, Özaydın Ö. Ethnobotany of Eskişehir and its environs. Pak J Bot 2013; 45: 207-14.

13. Coode MJE, Cullen J. Juniperus L. In: Davis PH (ed.) Flora of Turkey and the East Aegean Islands, Vol 1. Edinburgh Univ Press, Edinburgh. 1965, pp. 78-84.

14. Sezik E, Zor M, Yeşilada E. Traditional medicine in Turkey II. International. J Pharmacogn 1992; 30: 233-9.

15. Yeşilada E, Honda G, Sezik E, Tabata M, Goto K, Ikeshiro Y. Traditional medicine in Turkey IV. Folk medicine in the Mediterranean subdivision. J Ethnopharmacol 1993; 39: 31-8.

16. Ertuğ F. An ethnobotanical study in Central Anatolia (Turkey). Econ Bot 2000; 54: 155-82.

17. Salido S, Altarejos J, Nogueras M, Sanchez A, Pannecouque C, Witvrouw M, De Clercq E. Chemical studies of essential oils of Juniperus oxycedrus ssp. badia. J.Ethnopharmacol 2002; 81: 129-34.

18. Karaman I, Sahin F, Gulluce M, Ogutcu H, Sengul M, Adiguzel A. Antimicrobial activity of aqueous and methanol extracts of Juniperus oxycedrus L. J Ethnopharmacol 2003; 85: 231-5.

19. Park B, Park J, Lee D, Youn JI. Vitamin D receptor polymorphism is associated with psoriasis. J Invest Dermatol 1999;112:113-6.

20. Tan K. Aloe: In: Davis PH, Mill, Kit Tan (eds.). Flora of Turkey and the East Aegean Islands, Vol 8. Edinburgh Univ Press, Edinburgh. 1984, pp. 355.

21. Akev N, Turkay G, Can A, Gurel A, Yildiz F, Yardibi H. Tumor preventive effect of Aloe vera pulp lectin (Aloctin I) on Ehrlich ascites tumors in mice. Phytother Res 2007; 21:1070-5.

22. Rajendran PM, Young DM, Maurer T, Chambers HF, Jacobson MA, Harris HW. Antibiotic use in the treatment of soft tissue abscesses: a survey of current practice. Surg Infect 2007; 8:237-8.

23. Davis PH, Mill, Kit Tan. Flora of Turkey and the East Aegean
Islands, Vol 8. Edinburgh Univ Press, Edinburgh. 1984; pp. 71.

24. Vjayalakshmi A, Ravichandiran V, Malarkodi V, Nirmala S, Jayakumari S. Screening of flavonoid "quercetin" from the rhizome of Smilax china Linn. for anti-psoriatic activity. Asian Pac J Trop Biomed 2012; 2:269-75.

25. Salo OP, Kousa M, Mustak Allio KK, Lassus A. Demonstration of (ibrin in skin diseases. II. Psoriasis. Acta Derm Venereol (Stockh) 1972; 52:295- 7.

26. Evans WC. Trease and Evans pharmacognosy, 15th ed. WB Saunders, New York. 2002, pp 585.

27. Capasso F, Borrelli F, Capasso R, Di Carlo G, Izzo AA, Pinto L, Mascolo N, Castaldo S, Longo R. Aloe in its therapeutic use. Phytother Res 1998; 12: S124-7.

28. Panda H. Aloe vera handbook; cultivation, research findings, products, formulations, extraction \& processing. Delhi: Asia Pacific Business. 2004, pp. 496.

29. Bercu R, Broasca L, Popoviciu R. Comparative anatomical study of some gymnospermae species leaves. Bot Serb 2009; 34: 21-8.

30. Adams PR. Juniperus of the World: The genus Juniperus, 2nd edition. Trafford Publishing Co., Vancouver. 2008.

31. Esau K. Anatomy of seed plants, 2nd Ed. John Wiley \& Sons, New York. 1977.

32. Mauseth JD. Plant anatomy. The Benjamin/Cummings Publishing Company, Inc., Menlo Park, California. 1988.

33. Dickison WC. Integrative plant anatomy. Harcourt Academic Press, USA. 2000.

34. Güvenç A, Hürkul MM, Erdem A. The leaf anatomy of naturally distributed Juniperus L. (Cupressaceae) species in Turkey. Turk J Bot 2011; 35: 251-60.

35. Marquete O, Pontes RG. Estudo anatômico foliar comparativo de Smilax spicata Vell., Smilax rufescens Griseb., Smilax fluminensis Steudel. Rev Bras Biol 1994; 54: 413-26.

36. Palhares D, Silveira CES, Zaidan LBP, Pereira LAR. Leaf anatomy of Smilax goyazana (Smilacaceae). Acta Bot Hung 2009; 51: 115-27.

37. Palhares D, Silveira CES. Anatomy of rhizome of Smilax goyazana A. DC. (Smilacaceae). Braz J Med Plants 2005; 8: 52-62.

38. Palhares D. Pharmacognosy of the leaves of Eugenia dysenterica DC. (Myrtaceae Jussieu). Lecta 2003; 21: 29-36. 